\title{
Survival of Moss Reproductive Structures under Simulated Martian Environmental Conditions and Extreme Thermal Stress: Vibrational Spectroscopic Study and Astrobiological Implications
}

\author{
José María Gómez Gómez ${ }^{1^{*}}$, Belén Estébanez ${ }^{2}$, Aurelio Sanz-Arranz ${ }^{1}$, Eva Mateo-Martí ${ }^{3}$, Jesús Medina ${ }^{1}$ and Fernando Rull ${ }^{1}$ \\ ${ }^{1}$ Laboratory of Biomineralogy and Astrobiological Research (LBMARS), Av.Francisco Valles, 8. Parque Tecnológico de Boecillo, Parcela 203 E-47151, Boecillo \\ (Valladolid) Spain
}

${ }^{2}$ Departamento de Biología Vegetal, Facultad de Ciencias, Universidad Autónoma de Madrid, 28049 Cantoblanco, Spain

${ }^{3}$ Centro de Astrobiología (CSIC-INTA), Ctra. de Ajalvir km. 4, 28850-Torrejón de Ardoz, Madrid, Spain

*Correspondence author: José María Gómez Gómez, Laboratory of Biomineralogy and Astrobiological Research (LBMARS), Av.Francisco Valles, 8. Parque Tecnológico de Boecillo, Parcela 203 E-47151, Boecillo (Valladolid) Spain, E-mail: jmgomezseg@gmail.com

Received date: May 31, 2016; Accepted date: June 20, 2016; Published date: June 27, 2016

Copyright: (c) 2016 Gómez JMG, et al. This is an open-access article distributed under the terms of the Creative Commons Attribution License, which permits unrestricted use, distribution, and reproduction in any medium, provided the original author and source are credited.

\begin{abstract}
The principal goal of astrobiology is the search for extraterrestrial life forms. A key aspect is the study of the ability of different kinds of terrestrial organisms to support simulated extraterrestrial environmental conditions. Mosses are multicellular green plants, poorly studied from an astrobiological perspective. In this paper, we report experimental results obtained using two species of moss, which demonstrate that both the spores of the moss Funaria hygrometrica as well as the desiccated vegetative gametophyte shoots of the moss Tortella squarrosa (=Pleurochaete squarrosa) were capable of resisting Simulated Martian Environmental Conditions (SMEC): Mars simulated atmospheric composition $99.9 \% \mathrm{CO}_{2}$, and $0.6 \% \mathrm{H}_{2} \mathrm{O}$ with a pressure of 7 mbars, $-73{ }^{\circ} \mathrm{C}$ and UV irradiation of $30 \mathrm{~mW} \mathrm{~cm}^{-2}$ in a wavelength range of $200-400 \mathrm{~nm}$ under a limited short time of exposition of 2 hours. After being exposed to SMEC and then transferred to an appropriate growth medium, the $F$. hygrometrica spores germinated, producing typical gametophyte protonemal cells and leafy shoots. Likewise, detached leaves from SMEC-exposed gametophyte shoots of $T$. squarrosa retained the ability to produce new protonemata and shoots under suitable growth conditions. Furthermore, we studied the tolerance of these moss structures to a thermal stress of $100{ }^{\circ} \mathrm{C}$ for 1 $\mathrm{h}$; in both cases the spores and shoots were capable of resisting this heat treatment. Our study using FT-Raman and FT-IR vibrational spectroscopy demonstrated that neither spores nor shoots apparently suffered significant damage in their biomolecular makeup after being subject to these stress treatments. The implications of these findings for the search of life on Mars are discussed.
\end{abstract}

Keywords: Vibrational spectroscopy; Moss; Spores; Funaria hygrometrica; Dried gametophyte; Tortella squarrosa (=Pleurochaete squarrosa); Survival; Thermal stress; Biomarkers; Moss sporopollenin; Simulated Martian Environmental Conditions (SMEC)

\section{Introduction}

The search for life in extraterrestrial places is the principal objective of Astrobiology [1]. Important from an experimental point view, therefore, is the study of survival of terrestrial organisms under simulated extraterrestrial conditions and various conditions of stress [2]. For example, following this experimental approach, the survival of bacterial spores (e.g., Bacillus spores) under simulated martian environmental conditions (SMEC) has been reported [3,4] as well as their survival under extreme conditions of ultraviolet radiation $[5,6]$, heavy ions [7], simulated Mars solar radiation [8-11], low-pressure plasma [12], microgravity [13], outer space [14,15], Martian atmospheric pressure and composition [16], space vacuum and ultraviolet irradiation [17], and the comparative effects of several stresses on vegetative cells and spores [18] as well as under the environmental conditions of Jupiter's moon, Europe [19]. Survival of other bacteria, including an acidophilic chemolithotroph isolated from the Rio Tinto (Spain) and belonging to the Acidithiobacillus genus and Deinococcus radiodurans has been studied under SMEC [20], as well as methanogens under conditions of extreme dryness [21]. However, reports of investigations using higher organisms are scarce e.g., tardigrades, [22]; and cryptoendolithic fungi [23].

Bryophytes are an important group of photosynthetic land plants that produce spores and other reproductive structures (asexual vegetative propagules) during their lifecycle [24]. Although bryophytes were included in a proposal of a programme for biological terraforming of Mars [25], the astrobiological potential of bryophytes is still poorly explored [26].

Extant bryophytes belong either to liverworts (Marchantiophyta), mosses (Bryophyta, sensu strictu) or hornworts (Anthocerotophyta) [24]. Among all the land plants, only the bryophytes have a lifecycle that is dominated by the haploid gametophyte phase. This is a freeliving, multicellular and photosynthetic stage which, in most cases (all mosses and many liverworts), consists of leafy stems. These gametophytes bear gametangia (antheridia and archegonia), the gamete-producing structures. After fertilization and development of the embryo, the alternating diploid phase-the sporophyte, develops. It is always structured as a solitary capsule (the sporangium), often at the tip of an unbranched axis, the seta. The sporophyte is permanently attached to the maternal gametophyte, from which it obtains water, as well as nutrients at least in juvenile stages. Through meiosis, the sporophytic capsule generates and releases haploid spores which, after germination, produce new gametophytes, thus completing the cycle [24,27-29]. 
Citation: Gómez JMG, Estébanez B, Sanz-Arranz A, Mateo-Martí E, Medina J, et al. (2016) Survival of Moss Reproductive Structures under Simulated Martian Environmental Conditions and Extreme Thermal Stress: Vibrational Spectroscopic Study and Astrobiological Implications. Astrobiol Outreach 4: 151. doi:10.4172/2332-2519.1000151

Page 2 of 11

The most abundant bryophyte group is the Division Bryophyta or mosses. They are usually small plants with scarcely developed supporting tissue. Except for marine aquatic environments, they are able to colonize all habitats in which land plant life is possible, though they are rarely dominant in their ecosystems [29]. Most species are adapted to environments with poor nutrient supply, and are poikilohydric organisms, i.e., they are able to survive desiccated conditions and resume physiological activity after rehydration [30,31].

Both spores and vegetative propagules act as dispersive elements in mosses. Structurally, the spore wall consists of three layers, generally considered as comparable to those found in homologous structures in vascular plants [32]: An internal intine, an exine made of sporopollenin, and an external perine [33]. The intine is a polysaccharide wall containing cellulose, hemicelluloses and pectine. The main component of the exine is sporopollenin, an extremely resistant polymer. The composition of the perine is not completely determined, although sporopollenin and lipids seem to form part of its structure [34,35]. Sporopollenin is one of the most resistant natural polymers and so it also endows bryophyte spores with the ability to resist environmental stress such as desiccation, UV radiation, etc. $[24,31]$.

Following germination of spores and vegetative propagules, juvenile stages of moss gametophytes are not organized as leafy stems but as simple laminar or, more frequently, filamentous structures called protonemata (singular: protonema). There are usually two different types of protonemal phases in filamentous protonemata. The chloronema filaments form first; they grow apically, branch irregularly, and their cells are short with hyaline cell walls, right-angled cross walls and numerous discoidal chloroplasts. The caulonema consists of a set of filaments developed from the chloronema; it has longer cells with brownish walls, oblique crosswalls, and fewer fusiform chloroplasts. The caulonema gives rise to buds that develop into the leafy shoots of the adult gametophyte stages. These leafy shoots often produce filamentous rhizoids, closely resembling the juvenile caulonema $[29,31,36]$.

Funaria hygrometrica Hedw., a subcosmopolitan species, is one of the most common mosses and so one of the most studied species by bryologists [31,37-39]. It is a terricolous moss forming yellowish-green tufts of short, often unbranched shoots, in open, disturbed environments. It is one of the first species to colonize burned areas after a fire [39]. It reproduces mostly sexually, and its sporophyte has a characteristically long, flexuose seta and a large, pyriform capsule with an oblique mouth, producing yellowish or brownish spores, some $15-23 \mu \mathrm{m}$ in diameter [40].

Tortella squarrosa (Brid.) Lindb. (=Pleurochaete squarrosa (Brid.) Lindb., as it was widely known until its recent reconsideration into the genus Tortella: [41,42], is a widespread and common bryophyte in the Mediterranean Basin, with a sub-Mediterranean-sub-Atlantic distribution $[43,44]$. It is also a terricolous species growing in open, dry habitats, both grasslands and Mediterranean macchia. It often grows in human-disturbed habitats, including recently burned areas [45]. T. squarrosa is a dioecious species in which sporophyte production is very rare [46], and its propagation is therefore mainly asexual. It lacks morphologically differentiated propagules but it is able to regenerate from detached leaves [47], which function as vegetative diaspores.

Here, we report the results obtained from the study of the spore viability of the moss Funaria hygrometrica Hedw. and of gametophyte shoots of Tortella squarrosa (Brid.) Lindb. after being subject to SMEC treatment as well as thermal stress. Additionally we carried out FTRaman and FT-IR spectroscopic analyses of the materials before and after these treatments.

\section{Materials and Methods}

\section{Biological samples}

The plant material from Funaria hygrometrica Hedw, and Tortella squarrosa (Brid.) Limpr. used in this study were collected from sandy soil in Segurilla (Toledo), Spain $\left(40^{\circ} 02^{\prime} \mathrm{N},-4^{\circ} 84^{\prime}\right.$ E) in 09 May 2015. Voucher specimens are deposited at MAUAM (the herbarium of the Universidad Autónoma de Madrid).

\section{FT-Raman and FT-IR analysis}

The Raman spectra were recorded using a FT-Raman (Fourier transform Raman spectroscopy) device from Bruker, model RFS100/S. A $1064 \mathrm{~nm}$ laser from Klastech, Senza series was used as excitation source, with a CCD detector Bruker D418-T covering the spectral range from 851-1695 $\mathrm{nm}$ (giving a useful range of Raman Shift from $100-3500 \mathrm{~cm}^{-1}$ ). The recording conditions for all spectra were: Laser power on sample (nominal): $500 \mathrm{~mW}$. Diameter of laser spot on sample (nominal): $1000 \mu \mathrm{m}$, to avoid thermal damage of the sample. Slit aperture: $10 \mathrm{~mm}$. Best spectral resolution (nominal): $4 \mathrm{~cm}^{-1}$. Scan speed: $5 \mathrm{KHz}$. Scans number: 2048.

The FT-IR spectra by Attenuated Total Reflection analysis were performed with a device from Perkin Elmer, model Spectrum 100, and a Universal ATR Sampling Accesory. The recording conditions for all spectra: Spectral resolution of $4 \mathrm{~cm}^{-1}$ and 16 scans.

The FT-Raman and FT-IR spectra were obtained from bulk samples $\left(5 \times 10^{5}\right)$ of spores of $F$. hygrometrica and dried gametophytes of $T$. squarrosa.

\section{Optical and SEM Microscopy}

Microscope images were captured with an Ultralyt ULNM-90-10000 microscope (made by Brown \& Crown Company) and a ikon Eclipse E600 microscope coupled to a digital camera JVC TK-C1381EG. The scanning electron microscopy (SEM) was performed with a FEI-Quanta 200FEG electron microscope using an acceleration voltage of $5.00 \mathrm{keV}$. The SEM images were obtained using different scanning modes, through the detection of secondary electrons and from backscattered electrons.

\section{Spore and shoot viability experiments}

The viability of spores of $F$. hygrometrica and detached leaves from rehydrated gametophytes of T. squarrosa was tested as follows: The spores extracted from several mature capsules of $F$. hygrometrica were dusted on a microscope slide. The sample was divided into three parts. The control sample was transferred onto another microscope slide and was maintained at room temperature. A second sample was incubated in an oven at $100{ }^{\circ} \mathrm{C}$ for 1 hour, as a test of resistance to thermal stress. The third part was used to test resistance to SMEC. In parallel, several dried vegetative gametophyte shoots of $T$. squarrosa were incubated in an oven at $100{ }^{\circ} \mathrm{C}$ for 1 hour to test the effect of thermal stress. Other shoots were subjected to SMEC.

After each treatment, the gametophyte shoots were rehydrated and the leaves from these were detached. Following these treatments, the $F$. 
Citation: Gómez JMG, Estébanez B, Sanz-Arranz A, Mateo-Martí E, Medina J, et al. (2016) Survival of Moss Reproductive Structures under Simulated Martian Environmental Conditions and Extreme Thermal Stress: Vibrational Spectroscopic Study and Astrobiological Implications. Astrobiol Outreach 4: 151. doi:10.4172/2332-2519.1000151

hygrometrica spores and the detached, rehydrated leaves of $T$. squarrosa were inoculated onto semisolid agar in divided Petri dishes $(8.5 \mathrm{~cm}$ diameter, divided into three compartments) containing modified Bold 3N Medium [48]; the modification of this nutritive medium is detailed in UTEX, the culture collection of Texas University [49], jelli ied with agar powder (obtained from VWR chemicals) $(0.6 \%$, $6 \mathrm{~g} / \mathrm{L})$ at room temperature $\left(<25{ }^{\circ} \mathrm{C}\right)$. he Petri dishes were sealed with Parafilm and kept indirectly illuminated (with reflected light) for 30 days, followed by a further 30 days with the Petri dish unsealed, in both cases under the natural light-dark photoperiod (July-August 2015). At the end of the growth period, the Petri dishes and their contents were photographed using a digital camera Kodak EasyShare $\mathrm{Z} 710$.

\section{Image preparation}

The images in the figures were framed using Microsoft Photo Editor software and composed using the Powerpoint software program.

\section{Planetary atmosphere and surfaces chamber}

The SMEC experiments were performed in a specially designed environmental Planetary Atmospheres and Surfaces Chamber (PASC) at the Centro de Astrobiologia (Madrid) [50]. The samples were placed in a gold sample holder inside the PASC Chamber. The simulated Martian atmospheric composition was $99.9 \% \mathrm{CO}_{2}$ and $0.6 \% \mathrm{H}_{2} \mathrm{O}$ at a pressure of 7 mbars. Temperature was set at $-73{ }^{\circ} \mathrm{C}$, with the intention of simulating a very restrictive Martian environment. he ultraviolet radiation source was a Deuterium lamp with a dose emission of $30 \mathrm{~mW} \mathrm{~cm}^{-2}$ in the wavelength range 200-400 nm. he radiation spectrum of the lamp used in the experiments was similar to that previously published [20]. Total UV irradiation time was 2 hours, an accumulation dose equivalent to 0.5 Martian Sol (Sol $=$ Martian day; $24 \mathrm{~h} 37 \mathrm{~min}$ ) in the worst UV scenario (location $15^{\circ} \mathrm{S}$ and Ls 270) [20].

\section{Results}

\section{Scanning electron microscopy}

Figures 1A-1C show SEM images of the typical papillose ornamentation of the control spores, as previously described [29], the igures $1 \mathrm{D}-1 \mathrm{~F}$ correspond to micrographs of the SMEC-exposed spores. No visible differences (i.e., no structural damage) were observed in the exposed spores with respect to the control material. Figures 1G-1I show SEM micrographs from spores exposed to thermal stress $\left(100{ }^{\circ} \mathrm{C}, 1\right.$ hour $)$ showing no signi icant structural changes compared with the control spores (Figures 1A-1C). Remarkably, the spores exposed at $125^{\circ} \mathrm{C}$ for $1 \mathrm{~h}$, or at $150{ }^{\circ} \mathrm{C}$ for 30 minutes showed also a normal appearance in SEM images, but in these cases the spores lost their capacity to germinate (100\% of non survival) (data not shown).

Next we acquired information about the biochemical constituents of the spores. Raman spectroscopy (RS) and Infrared (IR) are nondestructive vibrational spectroscopic methods based on inelastic scattering of light or absorption of infrared light, respectively, by vibrating molecules. hese techniques have been widely used for both qualitative and semi-quantitative characterization of biological samples [51-54].

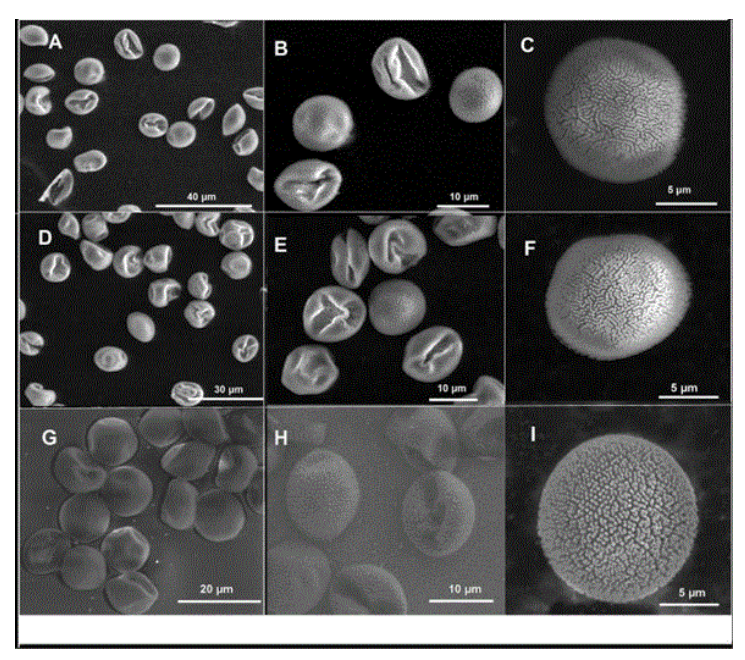

Figure 1: SEM images of $F$. hygrometrica spores. (A-C) SEM images at different magnifications of the control (non-exposed) spores (DF) SEM images at different magnifications of spores after exposure to SMEC conditions (G-I) SEM images of the spores after exposure to thermal stress $\left(100^{\circ} \mathrm{C}\right.$ for $\left.1 \mathrm{~h}\right)$.

\section{Raman spectroscopic analysis}

Raman spectroscopy is a non-destructive, label-free technique that is sensitive to biochemical variations and applicable to both in vitro and in vivo conditions, with minimum interference from water (compared with IR spectroscopy) [55]. Because the Raman spectrum depends on molecular structure (since it originates from the molecular vibration that is unique to each representative molecule) this spectroscopic analysis method provides unique and characteristic molecular fingerprints that identify different chemical species. Information about the biochemical makeup of a sample can be simply obtained by illuminating it with a low-power laser and analyzing the scattered light [56]. The characteristic peaks found in the Raman spectrum can be used to identify the molecular components or chemical composition of a sample [55].

The Raman spectrum obtained for a bulk biological sample composed of many independent entities (e.g., spores) is formed by the spectral convolution of the biomolecules present in this sample. The relative contribution of each component depends on its relative abundance as well as on the corresponding detection sensitivity (i.e., the incident laser wavelength) [52,56-58].

Figures $2 \mathrm{~A}(\mathrm{a})$ and $2 \mathrm{~A}(\mathrm{~b})$ show the typical FT-Raman spectra obtained from the bulk samples of $F$. hygrometrica spores before and after exposure to SMEC and to thermal stress. The characteristic Raman peaks are indicated and their tentative assignments are shown in Table 1.

\begin{tabular}{|l|l|l|}
\hline Wavenumber $\left(\mathbf{c m}^{-1}\right)$ & Components & Assignments \\
\hline $2923-2855$ & $\begin{array}{l}\text { Sporopollenin, lipids, } \\
\text { Carbohydrates }\end{array}$ & $\mathrm{C}-\mathrm{H} / \mathrm{C}-\mathrm{H}_{2} / \mathrm{C}-\mathrm{H}_{3}$ str \\
\hline 1660 & Proteins & C=O str, amide I \\
\hline 1606 & Sporopollenin, Phe & Aromatic ring str \\
\hline
\end{tabular}


Citation: Gómez JMG, Estébanez B, Sanz-Arranz A, Mateo-Martí E, Medina J, et al. (2016) Survival of Moss Reproductive Structures under Simulated Martian Environmental Conditions and Extreme Thermal Stress: Vibrational Spectroscopic Study and Astrobiological Implications. Astrobiol Outreach 4: 151. doi:10.4172/2332-2519.1000151

Page 4 of 11

\begin{tabular}{|l|l|l|}
\hline 1750 & Triglycerides, Lipids & Carboxyl ester C=O str \\
\hline 1524 & Carotenoids & Carotene $\mathrm{C}=\mathrm{C}$ str \\
\hline 1442 & Sporopollenin, Lipids & C- $\mathrm{H}_{2}$ def \\
\hline 1305 & Lipids, Proteins & Alkyl C- $\mathrm{H}_{2}$ bend, N-H str \\
\hline 1266 & Lipids & Alkyl=C-H cis str \\
\hline 1157 & Carotenoids & Carotene C-C str \\
\hline 1083 & Carbohydrates & $\begin{array}{l}\text { C-O-C str glycosidic link, } \\
\text { C-C skeletal, } \\
\text { C-O-H bending }\end{array}$ \\
\hline 1006 & Proteins, Carotenoids & $\begin{array}{l}\text { Phe ring breath, } \\
\text { roc }\left(\mathrm{C}-\mathrm{H}_{3}\right)\end{array}$ \\
\hline
\end{tabular}

Table 1: Relevant Raman peaks observed and identified in FT-Raman spectra from bulk samples of spores and tentative assignment of spectral features. Assignments for Raman bands (medium to strong bands only) were identified from the following references: Carbohydrates (including cellulose) [61,107] carotenoids [70-75], lipids [108], proteins [55,109], and sporopollenin [61]. Abbreviations: def, deformation; str, stretching; roc, rocking.

The FT-Raman spectrum of $F$ hygrometrica spores can be approximately divided into regions containing the signatures of carotenoids, lipids, proteins, carbohydrates and sporopollenin, respectively. Accordingly, this FT-Raman spectrum has two characteristic principal wavenumber regions: A dominant band in the range of $2700-3100 \mathrm{~cm}^{-1}$ corresponding to $\mathrm{C}-\mathrm{H}$ stretching (the bands most likely originate from $-\mathrm{CH}_{3},-\mathrm{CH}_{2}$, and $\mathrm{C}-\mathrm{H}$ functional groups in lipids and amino acid side chains of lipids, proteins and carbohydrates and sporopollenin (Figure 2A(a)) and a wide region at 850-1660 $\mathrm{cm}^{-1}$ with a band around $1442 \mathrm{~cm}^{-1}$ corresponding to $\mathrm{C}-\mathrm{H}_{2}$ deformation (Figure 2A(b)) [55].

As mentioned earlier, sporopollenin or sporopollenin-like material is a major component of moss spores. The chemical structure of these compounds is reported to be a series of diverse complex polymers derived from fatty acids and phenolic molecules [59,60]. The FTRaman spectra of pollen grains have been previously reported and several characteristic peaks associated with the presence of sporopollenin have been identified [61]. Assuming that sporopollenin from moss spores share a chemical structure similar to that from the pollen of vascular plants, we tentatively assigned the strong Raman peak at $1606 \mathrm{~cm}^{-1}$ of the $F$. hygrometrica spores to sporopollenin (Figure 2A(b)). The strong Raman signal would arise from ring stretches of phenyl structures. Other bands indicated in the figure are also believed to arise from sporopollenin [61], see Table 1 .

The presence of carotenoids in moss spores is also known [62,63]. These pigments act as a solar light screen, cutting out high-energy radiation (such as UV), so protecting DNA, lipid membranes and other cell components against oxidative damage induced by free radical production [64-66]. The most common carotenoids in mosses are lutein, zeaxanthin, $\beta$-cryptoxanthin and $\beta$-carotene. In Grimmia species they make up around $90 \%$ of the total carotenoid fraction [63]. All these, except lutein, have 11 conjugated $\mathrm{C}=\mathrm{C}$ bonds [66], and it has been demonstrated that their Raman spectra are close to that of the well documented $\beta$-carotene [67].

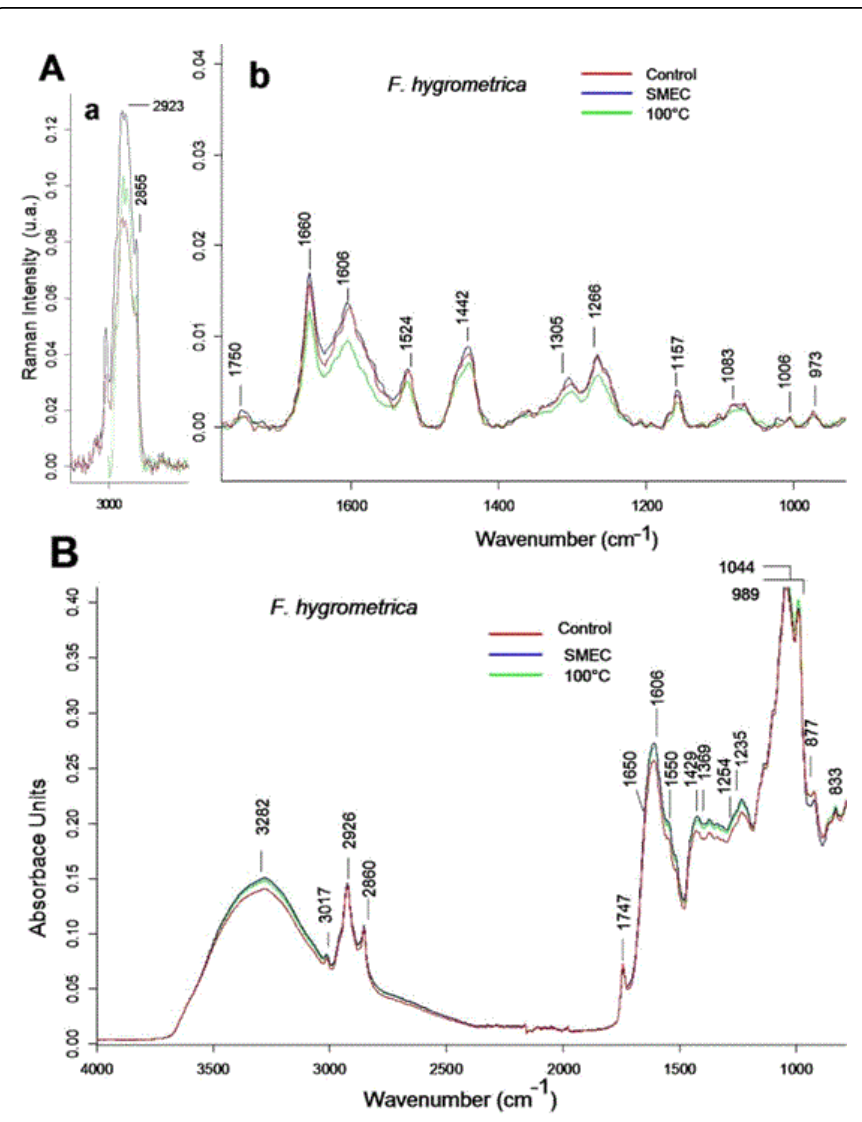

Figure 2: (A) FT-Raman of $F$. hygrometrica spores (a) FT-Raman obtained in the region $3100-2500 \mathrm{~cm}^{-1}$ (b) FT-Raman obtained in the region $1800-900 \mathrm{~cm}^{-1}$ (B) FT-IR spectra of spores of $F$. hygrometrica.

Carotenoids produce three characteristic peaks in the Raman spectrum [68-73]. Thus, $\beta$-carotene-a representative carotenoidexhibits two intense peaks at $1150 \mathrm{~cm}^{-1}$ and $1521 \mathrm{~cm}^{-1}$ arising from inplane stretching vibrations of $\mathrm{C}-\mathrm{C}$ and $\mathrm{C}=\mathrm{C}$ bonds respectively, and a third peak occurs at $1008 \mathrm{~cm}^{-1}$, created by an in-plane rocking movement of methyl groups $\left(\mathrm{CH}_{3}\right)$ connected to the polyene chain backbone [74]. Consequently, the Raman peaks labelled at 1606, 1157 and $1524 \mathrm{~cm}^{-1}$ in Figure 2A (b) and Table 1 are interpreted as deriving from the carotenoids in F. hygrometrica spores. Nonetheless, it is difficult to unambiguously identify individual carotenoids in biological samples using the Raman spectroscopy alone [74,75].

On the other hand, triglycerides have characteristic Raman bands [76-78] and moss spores are able to store triglycerides [79,80]. Hence, it would be expected that triglyceride signals should be clear in the Raman spectrum of the F. hygrometrica spores. As expected, a characteristic triglyceride peak is observed at $1266 \mathrm{~cm}^{-1}$. Figure $2 \mathrm{~A}(\mathrm{a})$ shows this, as well as a broad peak between 2800 and $3000 \mathrm{~cm}^{-1}$ that originates from the $-\mathrm{CH}_{3},-\mathrm{CH}_{2}$, and $\mathrm{C}-\mathrm{H}$ functional groups in triglycerides and lipids.

Proteins are another fundamental biomolecules that should be detected as spore constituents. The FT-Raman spectra of $F$. hygrometrica gives a clear peak at $1660 \mathrm{~cm}^{-1}$ that can be assigned tentatively to Amide I ( $\mathrm{C}=\mathrm{O}$ stretching) $[55,81]$. 
Citation: Gómez JMG, Estébanez B, Sanz-Arranz A, Mateo-Martí E, Medina J, et al. (2016) Survival of Moss Reproductive Structures under Simulated Martian Environmental Conditions and Extreme Thermal Stress: Vibrational Spectroscopic Study and Astrobiological Implications. Astrobiol Outreach 4: 151. doi:10.4172/2332-2519.1000151

Page 5 of 11

The most significant result of the Raman spectroscopic analysis is that there are no significant differences between the FT-Raman spectra of either the SMEC-exposed or the heat-treated F. hygrometrica spores compared to the control spectrum (Figures $2 \mathrm{~A}(\mathrm{a})$ and $2 \mathrm{~A}(\mathrm{~b})$ ).

\section{Infrared spectroscopic analysis}

Fourier transform infrared (FT-IR) spectroscopy probes the vibrational modes of molecules, providing a spectrum specific to each chemical structure [82-84]. FT-IR spectra can offer useful information about many different functional groups of biomacromolecules [54] and so it can be used to complement FT-Raman spectroscopy.

The FT-IR spectrum of $F$. hygrometrica spores (Figure 2B) can likewise be divided into regions containing the signatures of functional groups present in carotenoids, lipids, proteins, carbohydrates, and the wall biopolymers such as sporopollenin and pectin.

The FT-IR absorption bands in the $3600-2800 \mathrm{~cm}^{-1}$ spectral region were very broad and centred at approximately $3328 \mathrm{~cm}^{-1}$. This absorption bands located around $3328 \mathrm{~cm}^{-1}$ corresponds to $\mathrm{O}-\mathrm{H}$ and $\mathrm{N}-\mathrm{H}$ stretching (amide A) vibrations due mainly to proteins and carbohydrates. A sharp peak at $2926 \mathrm{~cm}^{-1}$ is due to the presence of polysaccharides, lipids, and carbohydrates (C-H stretch).

Moh et al. [85] described how the FT-IR spectrum for $\beta$-carotene exhibited peaks at $2922 \mathrm{~cm}^{-1}$ and $2862 \mathrm{~cm}^{-1}$ due to the asymmetric and symmetric stretching vibrations of the $\mathrm{CH}_{2}$ and $\mathrm{CH}_{3}$ groups. Thus, in the present study, the peaks at $2926 \mathrm{~cm}^{-1}$ and $2860 \mathrm{~cm}^{-1}$ could correspond to carotenoids; as well as the peaks at $1442 \mathrm{~cm}^{-1}$ (due to $\mathrm{CH}_{2}$ scissoring), $1369 \mathrm{~cm}^{-1}$ (due to splitting the dimethyl group). Other studies showed peaks associated with carotenoids at $1033 \mathrm{~cm}^{-1}$ (due to plane - $\mathrm{CH}$ - stretching) and $962 \mathrm{~cm}^{-1}$ (due to trans conjugated alkene $\mathrm{CH}=\mathrm{CH}$ - out-of-plane deformation) were not observed in the FT-IR spectra of F. hygrometrica spores, probably because their low intensity.

Three bands corresponding to protein absorption were observed in the FT-IR spectra of the F. hygrometrica spores. First, the amide I $\left(\mathrm{C}=\mathrm{O}\right.$ stretch) peak was located around $1650 \mathrm{~cm}^{-1}$ as a shoulder peak. Second, the amide II $1550 \mathrm{~cm}^{-1}$ peak (the amide II mode is the out-ofphase combination of the $\mathrm{N}-\mathrm{H}$ in-plane bend and the $\mathrm{C}-\mathrm{N}$ stretching vibration) is also observed as a shoulder. Thirdly, the peak at $1254 \mathrm{~cm}^{-1}$ corresponds to amide III vibration mode (which is the in-phase coupled N-H bending and C-N stretching vibrations of the peptide group). Absorption bands around $1747 \mathrm{~cm}^{-1}$ correspond to an isolated carbonyl group (COOR), indicating ester-containing compounds, which are commonly found in membrane lipid and cell wall pectin. [86]. The two main groups of lipids, triglycerides and phospholipids are characterized by the strong vibrational band around $1747 \mathrm{~cm}^{-1}$ ( $\mathrm{C}=\mathrm{O}$ stretching) [87].

The vibrational bands associated with carbohydrates are predominant the $1200-900 \mathrm{~cm}^{-1}$ spectral region (due to $\mathrm{C}-\mathrm{O}-\mathrm{C}, \mathrm{C}-$ $\mathrm{OH}, \mathrm{C}-\mathrm{O}$ stretching and $\mathrm{C}-\mathrm{C}, \mathrm{C}-\mathrm{O}-\mathrm{H}, \mathrm{C}-\mathrm{O}-\mathrm{C}$ deformation and pyranose and furanose ring vibrations $[55,86]$. Thus, the peak at 1040 $\mathrm{cm}^{-1}$ can be attributed to oligosaccharides, glycoprotein, and cellulose (C-O stretching) $[86,87]$.

The FT-IR spectrum of pollen was recently determined and showed characteristic sporopollenin absorption bands at 1605, 1515, 1171 and $833 \mathrm{~cm}^{-1}$, which can be associated with the vibrations of aromatic rings [88]. In the present study, the strong peak at $1606 \mathrm{~cm}^{-1}$ and the 833 $\mathrm{cm}^{-1}$ peak in the FT-IR spectrum of $F$. hygrometrica spores (Figure $2 \mathrm{~B}(\mathrm{~b}))$ are tentatively assigned to sporopollenin.
Importantly, as in the case of the FT-Raman spectra, the FT-IR spectra of F. hygrometrica spores of the SMEC and heat treatments showed no significant difference from the FT-IR control spectrum.

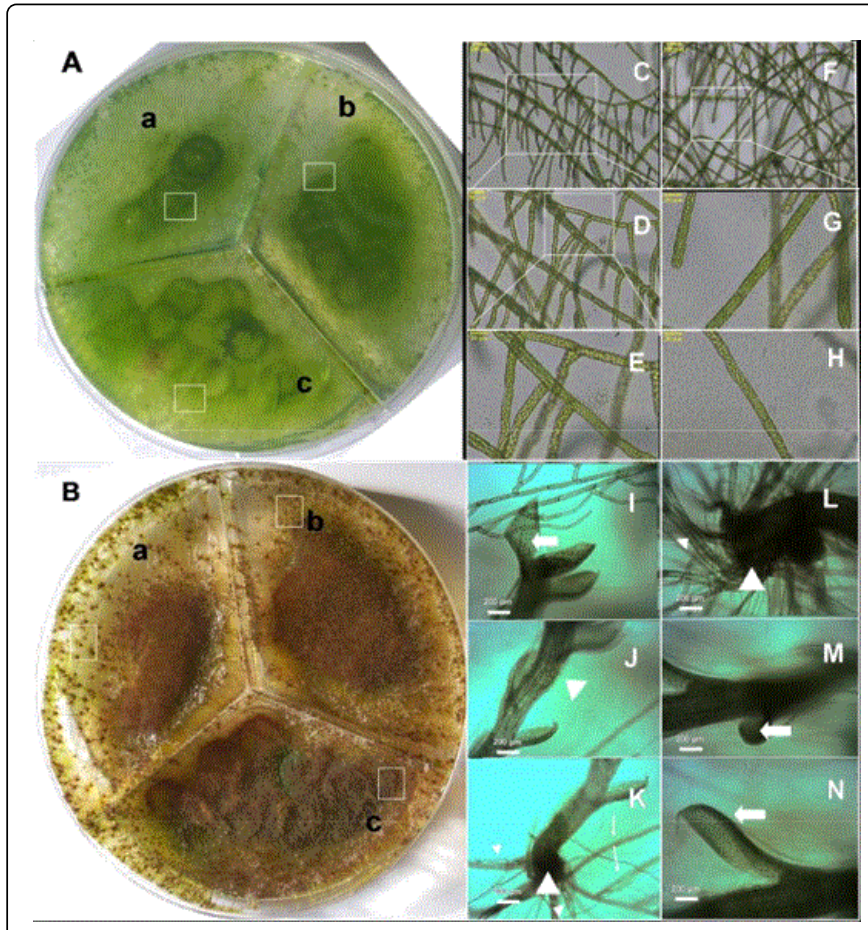

Figure 3: Survival of spores of F. hygrometrica to simulated Martian environmental conditions and thermal stress Bottom view of a divided Petri dish, with three differentiated areas; image taken after one month of growth and development since culture (a) Control area, inoculated with spores maintained at room temperature (b) Area inoculated with SMEC treated spores (c) Area inoculated with heat-exposed spores (B) Top view of the Petri dish (A) photographed after one additional month of growth and development of the same areas $(\mathrm{a}, \mathrm{b}$ and $\mathrm{c}$ ) labelled in $(\mathrm{A})(\mathrm{C}-\mathrm{H})$ Protonemata cells (chloronema) observed in situ in any of the boxes of the (a), (b) and (c) areas of Petri dish (A) (I-N) typical growth from spores, observed in situ in any of the areas (a), (b) and (c) of Petri dish (B) showing caulonema cells (thin arrows), and shoot stems (large arrowheads) with rhizoids (small arrowheads) and leaves (thick arrows). The brown aspect of the areas (a), (b) and (c) in the Petri dish image (B), is due to the reddish brown colour and bristling aspect of the rhizoid cells. The incident light on the Petri dish was from the bottom, thus the leafy gametophytes developed inside the agar medium, whereas the rhizoids developed vertically, standing out from the agar. Scale bars: $200 \mu \mathrm{m}$ (I-N); $100 \mu \mathrm{m}$ (C, F); $50 \mu \mathrm{m}(\mathrm{D}) ; 30 \mu \mathrm{m}(\mathrm{G}, \mathrm{E}, \mathrm{H})$.

\section{Survival of $\boldsymbol{F}$. hygrometrica spores after exposure to SMEC and thermal stress}

Taken together, these results suggest that the external architecture of F. hygrometrica spores, as well as the whole of its biochemical makeup, show resistance to SMEC and extreme thermal stress.

Given these results, we next investigated whether the apparent intactness of the spore structure and spectra might be correlated with 
Citation: Gómez JMG, Estébanez B, Sanz-Arranz A, Mateo-Martí E, Medina J, et al. (2016) Survival of Moss Reproductive Structures under Simulated Martian Environmental Conditions and Extreme Thermal Stress: Vibrational Spectroscopic Study and Astrobiological Implications. Astrobiol Outreach 4: 151. doi:10.4172/2332-2519.1000151

Page 6 of 11

an ability of the spores to germinate, i.e., that germinability is conserved intact. To test this possibility, approximately the same amount $\left(5 \times 10^{5}\right)$ of the SMEC-treated, heat-treated and non-treated (control) spores as indicated in Materials and Methods were cultured in Petri dishes. Figure 3 shows that the SMEC treated spores (Figure $3 \mathrm{~A}(\mathrm{~b})$ and heat treated spores (Figure $3 \mathrm{~A}(\mathrm{c})$ ) were able to germinate (95\% of germinability) producing characteristic protonemal cells (chloronema, Figures 3C-3H and caulonema, Figure $3 \mathrm{~K}$ and Figure $3 \mathrm{~L}$ ), and fully developed leafy gametophytes (Figures 3I-3N) with a characteristic stem and rhizoids (Figure $3 \mathrm{~K}$ and Figure $3 \mathrm{~L}$ )), similar to those developed by the control spores (Figure $3 \mathrm{~A}(\mathrm{a})$ ).

Taken together with the spectral analyses, these results indicate that the spores of $F$. hygrometrica are capable of resisting the simulated Martian environmental conditions and thermal stress.

\section{Vibrational spectroscopy and survival of Tortella squarrosa following SMEC and thermal stress}

The investigation was then extended to another moss species and to biological material other than spores by exposing dried gametophyte shoots of T. squarrosa separately to SMEC and thermal stress, as described in the Materials and Methods section.

Figure 4A shows the FT-Raman spectra and Figure 4B shows the FT-IR spectra of whole gametophyte shoots before and after undergoing these treatments. Figure 5 compares the FT-Raman and FT-IR spectra of $F$. hygrometrica spores vs. desiccated gametophyte shoots of T. squarrosa.

Several important results are shown in these spectra: No appreciable differences were observed between the FT-Raman spectra from either the SMEC or the heat-treated T. squarrosa shoots compared to the control (Figures $4 \mathrm{~A}(\mathrm{a})$ and $4 \mathrm{~A}(\mathrm{~b})$ ), with the sole exception that the peak at $1006 \mathrm{~cm}^{-1}$ was more intense in the SMEC treated material than in the control.

Likewise, the FT-IR spectra of the T. squarrosa control, SMEC and heat treated samples were similar, the only difference being a weak peak at $3697 \mathrm{~cm}^{-1}$ in the FI-IR obtained for the SMEC sample.

The peak at $1607 \mathrm{~cm}^{-1}$ that was tentatively assigned in the $F$. hygrometrica spores to sporopollenin is also observed in the Raman spectrum of T. squarrosa. In the gametophytes, this peak could be due to the presence of phenyl groups of other components (e.g., phenylalanine of proteins). The three expected characteristic carotenoid Raman peaks were also observed in the gametophytes at $1006 \mathrm{~cm}^{-1}, 1156 \mathrm{~cm}^{-1}$ and $1520 \mathrm{~cm}^{-1}$.

The FT-Raman and FT-IR spectra of dried gametophyte shoots of $T$. squarrosa show a clear and marked difference in the region between $1700-800 \mathrm{~cm}^{-1}$ when is compared with the $F$. hygrometrica spores spectra (Figure 5). An Amide I peak $\left(1660 \mathrm{~cm}^{-1}\right)$ is observed in the FTRaman spectrum of T. squarrosa (Figure 4A(b) and Figure 5A) but it is much less intense than for F. hygrometrica spores. This probably indicates that the protein content of the spores is higher than in the $T$. squarrosa gametophytes.

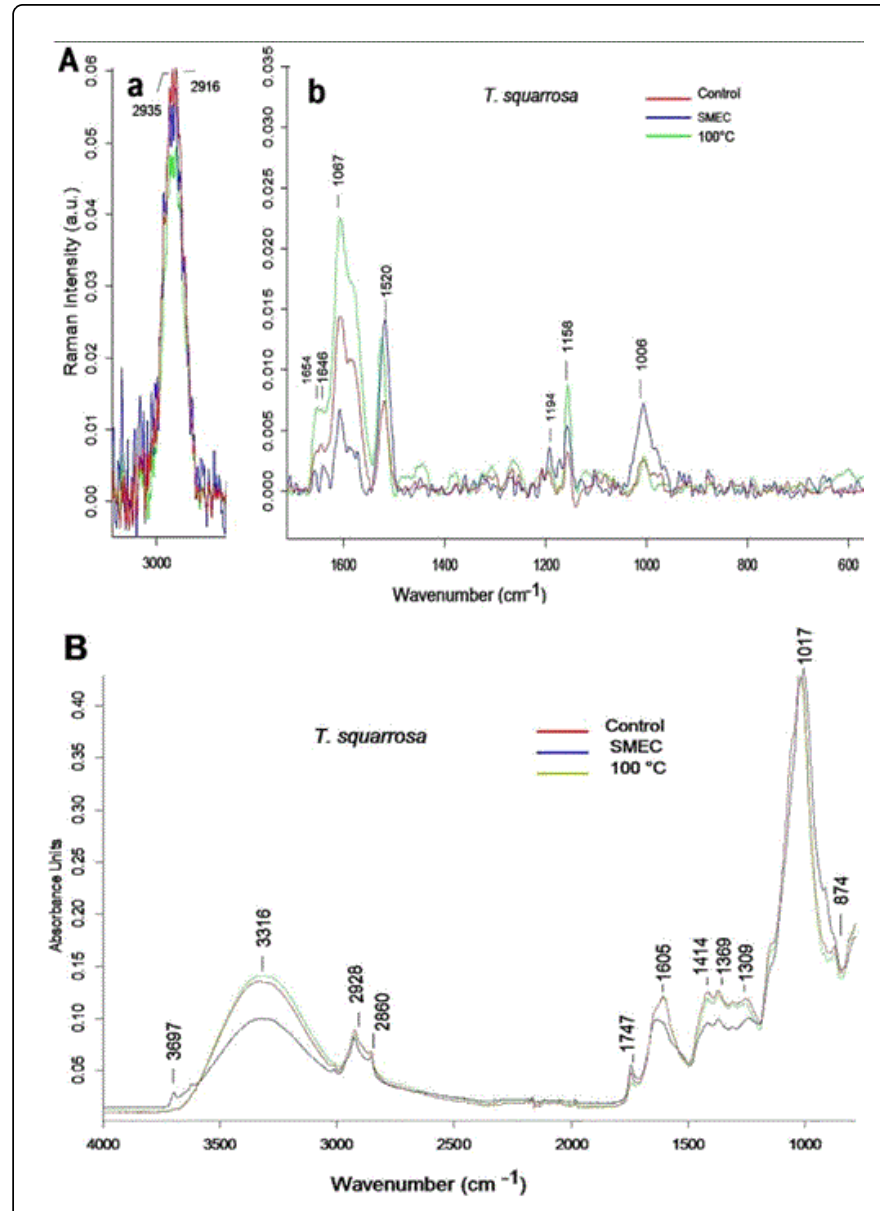

Figure 4: FT-Raman and FT-IR spectra of the desiccated gametophytes of $T$. squarrosa (A) FT-Raman spectra of dried gametophytes, control, SMEC treated, and heat treated (B) FT-IR spectra of control, SMEC treated, and heat treated.

The Raman peak around $1442 \mathrm{~cm}^{-1}\left(\mathrm{C}-\mathrm{H}_{2}\right.$ deformation) that was seen in the spores of $F$. hygrometrica is completely absent in the FTRaman spectrum of T. squarrosa (Figure 5A). This could be explained if the F. hygrometrica peak was produced mainly by sporopollenin, which is absent from the leafy gametophyte of T. squarrosa. Neither were there any spectral bands at $1200-1400 \mathrm{~cm}^{-1}$ and $1050-1100 \mathrm{~cm}^{-1}$. Finally, a strong peak at $1007 \mathrm{~cm}^{-1}$ is produced in the Raman spectrum of T. squarrosa compared with the spectrum of the F. hygrometrica spores.

The FT-IR spectra were very similar for both species (Figure 5B). However, the peak intensity of the FT-IR spectrum of the desiccated leafy gametophyte of T. squarrosa was clearly lower in the 1100-1700 $\mathrm{cm}^{-1}$ region than in the corresponding FT-IR of $F$. hygrometrica spores, indicating that the biological materials that produce these peaks occur in greater amounts in the F. hygrometrica spores.

The next step was to test the ability of the gametophyte shoots to produce new protonemata and leafy gametophytes. To do this, detached leaves (approximately 100) of treated shoots were rehydrated and grown in Petri dishes (see Materials and Methods). Figure 6 shows that the SMEC-exposed gametophyte shoots maintain intact their 
Citation: Gómez JMG, Estébanez B, Sanz-Arranz A, Mateo-Martí E, Medina J, et al. (2016) Survival of Moss Reproductive Structures under Simulated Martian Environmental Conditions and Extreme Thermal Stress: Vibrational Spectroscopic Study and Astrobiological Implications. Astrobiol Outreach 4: 151. doi:10.4172/2332-2519.1000151

Page 7 of 11

ability (90\% of survival) to generate new protonemata (Figures $6 \mathrm{C}-6 \mathrm{E}$ ) and shoots (Figures 6F and 6G).

Likewise, the detached leaves from gametophytes (approximately $100)$ that were subjected to heat stress $\left(1 \mathrm{~h}\right.$ at $\left.100{ }^{\circ} \mathrm{C}\right)$ were also able to produce new shoots (Figures $6 \mathrm{H}-6 \mathrm{~J}$ ) and protonemata (Figures $6 \mathrm{~K}-6 \mathrm{M})$ (85\% of survival). In contrast, the detached leaves of $T$. squarrosa that were heat-treated for $1 \mathrm{~h}$ at $125^{\circ} \mathrm{C}$, were unable to generate novel protonemata ( $100 \%$ of non-survival) (data not shown).

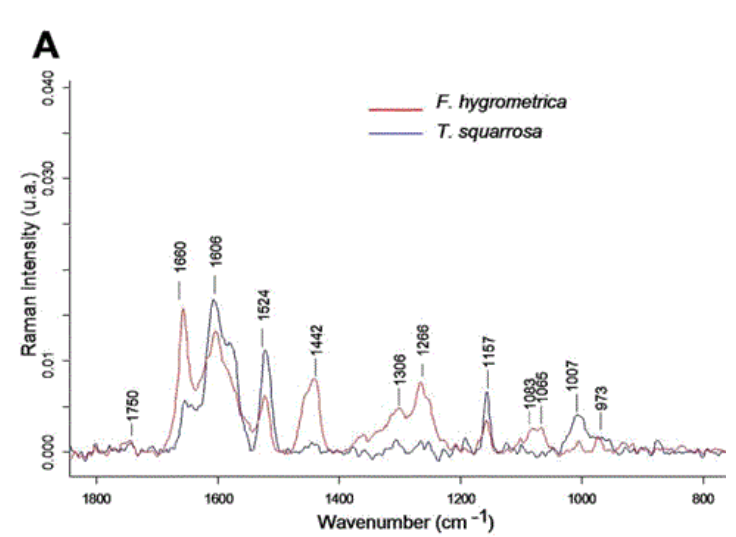

\section{B}

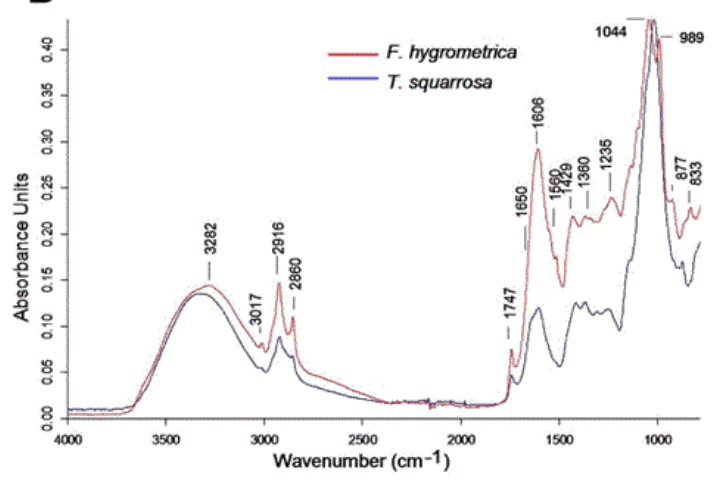

Figure 5: Comparative vibrational spectroscopy between desiccated gametophytes of T. squarrosa vs. spores of F. hygrometrica (A) FTRaman spectra (B) FT-IR spectra.

\section{Discussion}

In this paper, we present the first experimental evidence that different structures from mosses, namely both the sexual spores of $F$. hygrometrica and the vegetative gametophyte shoots of T. squarrosa, are capable of resisting simulated Martian environmental conditions.

Although there are some recent reports of FT-IR spectra [86,87] and Raman spectra [89] for gametophytes of some moss species, this is the first time to our knowledge that FT-Raman and FT-IR spectra are reported for moss spores. As presented in the Introduction section, both species here studied are known to live in open, thermophilous soils, are able to resist heavy disturbance and favour recently burned areas. Previous experiments have shown their thermal resistance: Survival of $F$. hygrometrica spores subjected to autoclaving [90] and resistance to heat (at $100{ }^{\circ} \mathrm{C}$ for 30 minutes) of $T$. squarrosa shoots [91]. Our results confirm these reports and extend the resistance of $T$. squarrosa shoots to one hour at the same temperature. Bonifacio et al. [89] suggested that spectral bands due to other biochemical species expected to be found in mosses (such as proteins, sugars, lipids and nucleic acids) are not observed because their Raman signals are obscured by carotenoid bands, whose intensity is selectively enhanced by several orders of magnitude due to the resonance Raman (RR) effect [74]. Contrary to this expectation, the Raman spectra of $F$. hygrometrica spores and dried shoots of T. squarrosa, do contain Raman signals corresponding to proteins. Some taxonomical differences might be involved since [89] used a different moss genus, Grimmia, for their study.

There are a number of astrobiological implications based on the findings of this study:

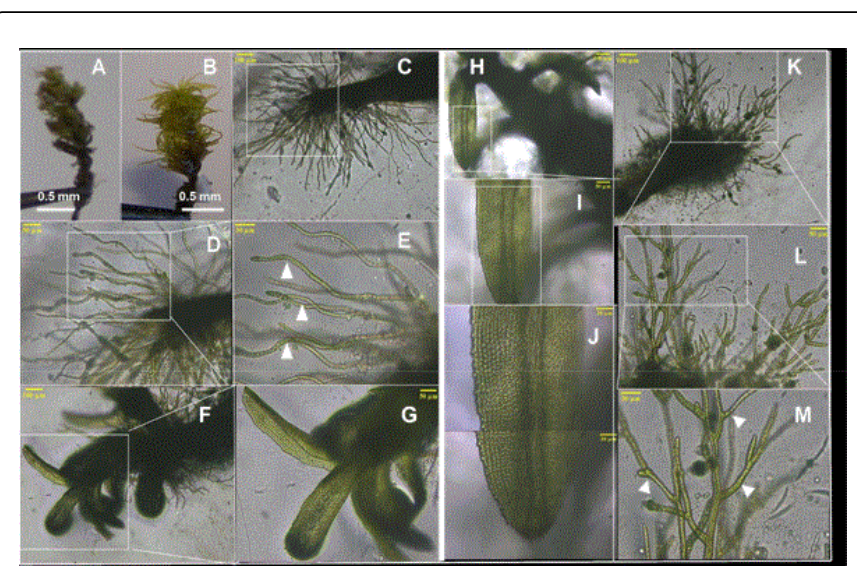

Figure 6: Survival of shoots of Tortella squarrosa to simulated Martian environmental conditions and thermal stress (A) Light field micrographs of a desiccated shoot used in the experiments. (B) The same shoot after rehydration (C) A rehydrated, detached leaf after SMEC treatment, showing protonemata developing on semisolid agar (C-E) Chloronema development: Typical chloronemal green cells with hyaline walls are indicated in (E) with arrowheads (D) enlargement of the box in C (F-G) New shoot developed from a SMEC-exposed detached leaf showing novel emerging leaves (H-J) New shoot developed from a heat-exposed detached cell after showing a newly developed leaf. (K-M) New protonemata generated from a heat-treated, detached leaf. The chloronema cells are indicated with arrowheads. Scale bars: $0.5 \mathrm{~mm}$ (A, B); $100 \mu \mathrm{m}$ (C, F, H, K); $50 \mu \mathrm{m}(\mathrm{D}, \mathrm{G}, \mathrm{L}) ; 30 \mu \mathrm{m}$ (E, J, M).

\section{Raman spectra and search for life on Mars}

As previously commented, Raman spectroscopy can provide information about the chemistry of a sample quickly and nondestructively. Due to this property, the ESA ExoMars planetary mission scheduled for launch in 2018 will contain a miniaturized Raman spectrometer (the Raman Laser Spectrometer, RLS) as part of the Pasteur payload to interrogate crushed samples from the surface or shallow subsurface [92-94]. Our group is the RLS developer and has the goal of investigating mineralogy and searching for organic compounds and signs of life [95]. Additionally, NASA is independently developing a miniaturized Raman spectrometer for a future Mars mission planned for 2020, also in collaboration with our group. Accordingly, it is very important to obtain Raman spectra for the most representative biological specimens of the three domain of life on 
Citation: Gómez JMG, Estébanez B, Sanz-Arranz A, Mateo-Martí E, Medina J, et al. (2016) Survival of Moss Reproductive Structures under Simulated Martian Environmental Conditions and Extreme Thermal Stress: Vibrational Spectroscopic Study and Astrobiological Implications. Astrobiol Outreach 4: 151. doi:10.4172/2332-2519.1000151

Page 8 of 11

Earth: Bacteria, Archaea and Eucarya [96] in order to try to understand the ability of these different kinds of living organisms to resist different extraterrestrial environmental conditions. Our results open this possibility for moss reproductive structures in Mars conditions.

\section{Sporopollenin as a new biomarker}

Different kinds of organic chemicals have been reported as biomarkers (e.g., carotenoids $[73,97])$. Sporopollenin present in spore and pollen walls is a resistant polymer that can allows the organism to resist extreme conditions of environmental. As an example, some spores have survived and remained viable after thousands of years in permafrost sediments [98]. Sporopollenin-covered spores of putative early land plants, probably including bryophytes, have been recovered from sediments from the Ordovician, Silurian and Devonian periods, having resisted decay [99-101], although it is often difficult to assign them to a particular plant group [102]. Hence, the ability of spores to survive over geological timescales is an important trait from an astrobiological perspective.

Furthermore, a more detailed study of the Raman spectra of sporopollenin and sporopollenin-like compounds might show up significant differences across the different plant groups. Accordingly, we suggest that Raman peaks of sporopollenins may constitute interesting biomarkers.

\section{Future investigation}

Some recently published results by Kral et al. [103] report that methanogens thrive long time (days) in constant exposure to Mars-like conditions that simulate the environmental conditions of the Martian subsoil. Although the time of exposition in our experiments reported here is shorter $(2 \mathrm{~h})$, nevertheless they represent an accurate simulation of the harsh Martian conditions on its surface rather than the subsoil. The UV radiation, for instance, is a critical environmental factor in Mars surface that subsoil methanogens would not have to face. Therefore, taking into account these successful results of survival under two hours of exposition of the moss reproductive structures, we consider that this time, although apparently short, represent a bona fide exposition to SMEC conditions because all parameters of the Mars surface-pressure, temperature, humidity, $\mathrm{CO}_{2}$ composition, and UV irradiation- are simultaneously considered. However, in future experiments under SMEC treatment, the time will be extended beyond two hours, obtaining thus others UV accumulation times, simulating in this way different numbers of Martian Sols.

In addition to Mars, other possible targets in the search for extraterrestrial life include the icy moons of Jupiter (Europa) and Saturn (Enceladus) [104]. Our next investigation will be a study of the viability of $F$. hygrometrica spores and $T$. squarrosa under the environmental conditions reported for these extraterrestrial moons. An upper limit for thermal stress resistance in eukaryotes has been reported for Syntrichia caninervis [105]. It will be interesting to test the ability of these moss species to resist Mars, Europa and Enceladus environmental conditions.

\section{Conclusion}

We have presented evidence that the germinability of spores of the moss $F$. hygrometrica persists after exposure to simulated Martian environmental conditions. In addition, we found that the ability of detached leaves of the moss T. squarrosa to produce new protonemata and shoots remains intact after an SMEC treatment. Resistance to thermal stress exposure was observed for both kinds of moss structures. These results indicate that non-bacterial spores (i.e., from an organism of the Eucarya domain) are capable of resisting Martian conditions. Hence, these findings suggest the possibility of finding biomarkers associated with these structures might be considered in the search for Life on Mars [106].

\section{Acknowledgements}

The authors express their gratitude to M.A. Moreno from the Unidad de Microscopia Avanzada de la Fundacion Parque Cientifico, Universidad de Valladolid for his technical support. The research was supported by the Spanish Ministerio de Economia y Competividad (MINECO): Grant No ESP2013-48427-C3-2-R and No ESP2014-55851-C2-2-P.

\section{References}

1. Gilmour I, Sephton MA (2004) An Introduction to Astrobiology. Cambridge University Press. Cambridge, UK.

2. Kolb VM (2014) Astrobiology: an Evolutionary Approach. CRC Press.

3. Schuerger AC, Mancinelli RL, Kern RG, Rothschild LJ, McKay CP (2003) Survival of endospores of Bacillus subtilis on spacecraft surfaces under simulated martian environments: implications for the forward contamination of Mars. Icarus 165: 253-276.

4. Wassmann M, Moeller R, Rabbow E, Panitz C, Horneck G, et al. (2012) Survival of spores of the UV-resistant Bacillus subtilis strain MW01 after exposure to low-earth orbit and simulated martian conditions: data from the space experiment ADAPT on EXPOSE-E. Astrobiology 12: 498-507.

5. Elasri MO, Miller RV (1999) Study of the response of a biofilm bacterial community to UV radiation. Appl Environ Microbiol 65: 2025-2031.

6. Schuerger AC, Richards JT, Newcombe DA, Venkateswaran K (2006) Rapid inactivation of seven Bacillus spp. Under simulated Mars UV irradiation. Icarus 181: 52-62.

7. Baltschukat K, Horneck G, Bücker H, Facius R, Schäfer M (1986) Mutation induction in spores of Bacillus subtilis by accelerated very heavy ions. Radiat Environ Biophys 25: 183-187.

8. Tauscher C, Schuerger CA, Nicholson LW (2006) Survival and germinability of Bacillus subtilis spores exposed to simulated Mars solar radiation: implications for life detection and planetary protection. Astrobiology 6: 592-605.

9. Dose K, Gill M (1995) DNA stability and survival of Bacillus subtilis spores in extreme dryness. Orig Life Evol Biosph 25: 277-293.

10. Dose K, Klein A (1996) Response of Bacillus subtilis spores to dehydration and UV irradiation at extremely low temperatures. Orig Life Evol Biosph 26: 47-59.

11. Setlow P (2006) Spores of Bacillus subtilis: their resistance to and killing by radiation, heat and chemicals. J Appl Microbiol 101: 514-525.

12. Stapelmann K, Fiebrandt M, Raguse M, Awakowicz P, Reitz G, et al. (2013) Utilization of low-pressure plasma to inactivate bacterial spores on stainless steel screws. Astrobiology 13: 597-606.

13. Sugiura K, Hashimoto H, Ishikawa Y, Kawasaki Y, Kobayashi K, et al. (1999) Cultivation of bacteria with ecological capsules in space. Adv Space Res 23: 405-408.

14. Vaishampayan PA, Rabbow E, Horneck G, Venkateswaran KJ (2012) Survival of Bacillus pumilus spores for a prolonged period of time in real space conditions. Astrobiology 12: 487-497.

15. Horneck G, Moeller R, Cadet J, Douki T, Mancinelli RL, et al. (2012) Resistance of bacterial endospores to outer space for planetary protection purposes--experiment PROTECT of the EXPOSE-E mission. Astrobiology 12: 445-456.

16. Nicholson LW, Schuerger CS (2005) Bacillus subtilis spore survival and expression of germination-induced bioluminescence after prolonged 
Citation: Gómez JMG, Estébanez B, Sanz-Arranz A, Mateo-Martí E, Medina J, et al. (2016) Survival of Moss Reproductive Structures under Simulated Martian Environmental Conditions and Extreme Thermal Stress: Vibrational Spectroscopic Study and Astrobiological Implications. Astrobiol Outreach 4: 151. doi:10.4172/2332-2519.1000151

Page 9 of 11

incubation under simulated Mars atmospheric pressure and composition: implications for planetary protection and lithopanspermia. Astrobiology 5: 536-544.

17. Saffary R, Nandakumar R, Spencer D, Robb FT, Davila JM, et al. (2002) Microbial survival of space vacuum and extreme ultraviolet irradiation: strain isolation and analysis during a rocket flight. FEMS Microbiol Lett 215: 163-168.

18. Diaz B, Schulze-Makuch D (2006) Microbial survival rates of Escherichia coli and Deinococcus radiodurans under low temperature, low pressure, and UV-Irradiation conditions, and their relevance to possible Martian life. Astrobiology 6: 332-347.

19. Noell AC, Ely T, Bolser DK, Darrach H, Hodyss R, et al. (2015) Spectroscopy and viability of Bacillus subtilis spores after ultraviole irradiation: implications for the detection of potential bacterial life on Europa. Astrobiology 15: 20-31.

20. Gómez F, Mateo-Martí E, Prieto-Ballesteros O, Martín-Gago J, Amils R (2010) Protection of chemolithoautotrophic bacteria exposed to simulated Mars environmental conditions. Icarus 209: 482-487.

21. Kendrick MG, Kral TA (2006) Survival of methanogens during desiccation: implications for life on Mars. Astrobiology 6: 546-551.

22. Jönsson KI (2007) Tardigrades as a potential model organism in space research. Astrobiology 7: 757-766

23. Onofri S, de Vera JP, Zucconi L, Selbmann L, Scalzi G, et al. (2015) Survival of Antarctic Cryptoendolithic Fungi in Simulated Martian Conditions On Board the International Space Station. Astrobiology 15: 1052-1059.

24. Shaw JA, Goffinet B (2000) The Biology of Bryophytes. Cambridge, England: Cambridge University Press.

25. Graham JM (2004) The biological terraforming of Mars: planetary ecosynthesis as ecological succession on a global scale. Astrobiology 4: 168-195.

26. Kern VD, Schwuchow JM, Reed DW, Nadeau JA, Lucas J, et al. (2005) Gravitropic moss cells default to spiral growth on the clinostat and in microgravity during spaceflight. Planta 221: 149-157.

27. Schofield WB (1985) Introduction to Bryology. New York: Macmillan.

28. Miles CJ, Longton RE (1990) The role of spores in reproduction in mosses. Bot J Linn Soc 104: 149-173.

29. Vanderpoorten A, Goffinet B (2009) Introduction to Bryophytes. Cambridge University Press.

30. Chopra RN, Kumra PK (1988) Biology of Bryophytes. John Wiley and Sons, New York.

31. Crum H (2001). Structural diversity of bryophytes. University of Michigan Herbarium. Ann Arbor, p: 379.

32. Afzelius BM (1957) On new methods in physical cell research and their application in studies on pollen grain and spores. In Pollen and Spore Morphology. Plant Taxonomy. Gymnospermae, Pteridophyta, Bryophyta. In: Erdtman G (ed.). Almqvist \& Wiksell, Stockholm and Ronald Press, New York USA 125-134.

33. McClymont JW, Laeson DA (1964) An electron-microscope study of spore wall structure in the Musci. Am J Bot 51: 195-200.

34. Neidhart HV (1979) Comparative studies of sporogenesis in bryophytes. In Bryophyte systematics. Clarke GCS and Duckett JO (eds.), London Academic Press 251-280.

35. Brown RC, Lemmon BE (1990) Sporogenesis in bryophytes. In Microspores, evolution and ontogeny. edn. Blackmore, S, Knox R. B. London Academic Press 55-94.

36. Nehira K (1983) Spore germination, protonema development and sporeling development. In New Manual of Bryology. Schuster RM (edn), The Hattori Botanical Laboratory, Nichinan 343-385.

37. Hoffman GR (1970) Spore viability in Funaria hygrometrica. Bryologist 73: 634-635.

38. Nakosteen PC, Hughes KW (1978) Sexual life cycle of three species of Funariaceae in culture. The Bryologist 81: 307-314.

39. Crum HA (1983) "Funaria Hedw." Mosses of the Great Lakes Forest. $3^{\text {rd }}$ edn. Ann Arbor, MI: University of Michigan Herbarium, pp: 135-137.
40. Brugués M, Ruiz E (2010) Funaria hygrometrica. In: Flora Briofítica Iberica IV. Funariales, Splachnales, Schistostegales, Bryales, Timmiales. In: Guerra J, Brugués M, Cano MJ, and Cros RM U(eds.), Universidad de Murcia \& Sociedad Española de Briología 60-63.

41. Werner O, Ros RM, Grundmann M (2005) Molecular phylogeny of Trichostomoideae (Pottiaceae, Bryophyta) based on nrITS sequence data. Taxon 54: 361-368

42. Grundmann M, Schneider H, Russell SJ, Vogel JC (2006) Phylogenetic relationships of the moss genus Pleurochaete Lindb. (Bryales: Pottiaceae) based on chloroplast and nuclear genomic markers. Org Divers Evol 6: 33-45.

43. Izquieta-Rojano S,Elustondoa D, Ederra A, Lasheras E, Santamaría C, et al. (2016) Pleurochaete squarrosa (Brid.) Lindb. as an alternative moss species for biomonitoring surveys of heavy metal, nitrogen deposition and d $15 \mathrm{~N}$ signatures in a Mediterranean area. Ecol Indic 60: 1221-1228.

44. Grundmann M, Ansell SW, Russell SJ, Koch MA, Vogel JC (2007) The genetic structure of the widespread and common Mediterranean bryophyte Pleurochaete squarrosa (Brid.) Lindb. (Pottiaceae) - evidence from nuclear and plastidic DNA sequence variation and allozymes. Mol Ecol 16: 709-722.

45. Heras-Ibáñez J, Guerra-Montes J, Herranz-Sanz JM (1994) Algunos datos sobre la sucesión briofítica colonizadora de bosques quemados del sureste de España. Studia Bot 13: 191-194.

46. Fernández-Mendoza F, Estebánez B, Gómez-Sanz D, Ron E (2002) Sporophyte-bearing specimens of Pleurochaete squarrosa in Zamora, Spain. Cryptogam Bryol 23: 211-215.

47. Giordano S, Alfano F, Esposito A, Spagnuolo V, Basile A, et al. (1996) Regeneration from detached leaves of Pleurochaete squarrosa (Brid.) Lindb. in culture and in the wild. J Bryology 19: 219-227.

48. Bischoff HW, Bold HC (1963) Phycological studies IV. Some soil algae from enchanted rock and related algal species. University of Texas Publication No. 6318, Austin, Texas.

49. Starr RC, Zeikus JA (1993) - UTEX - The culture collection of algae at the University of Texas at Austin. J Phycol 29: 1-106.

50. Mateo-Martí E, Prieto-Ballesteros O, Sobrado JM, Gómez-ElviraJ, Martín-Gago JA (2006) A chamber for studying planetary environments and its applications to astrobiology. Meas Sci Technol 17: 1-7.

51. Parker FS (1983) Applications of infrared, Raman, and resonance Raman spectroscopy in biochemistry. Springer, Berlin.

52. Lasch P, Kneipp J (2008) Biomedical Vibrational Spectroscopy. Hoboken, NJ: Wiley.

53. Stuart B (2005) Infrared Spectroscopy: Fundamentals and Applications. John Wiley and Sons.

54. Baker MJ, Trevisan J, Bassan P, Bhargava R, Butler HJ, et al. (2014) Using Fourier transform IR spectroscopy to analyze biological materials. Nat Protoc 9: 1771-1791.

55. Maquelin K, Kirschner C, Choo-Smith LP, van den Braak N, Endtz HP, et al. (2002) Identification of medically relevant microorganisms by vibrational spectroscopy. J Microbiol Methods 51: 255-271.

56. Schmitt M, Popp J (2006) Raman spectroscopy at the beginning of the twenty-first century. J Raman Spectrosc 37: 20-28.

57. McCreery RL (2000) Raman spectroscopy for Chemical Analysis. New York: Wiley.

58. Rösch P, Schmitt M, Kiefer W, Popp J (2003) The identification of microorganisms by micro-Raman spectroscopy. J Mol Struct 661-662: 363-369.

59. Guilford WJ, Schneider DM, Labovitz J, Opella SJ (1988) High resolution solid state C NMR spectroscopy of sporopollenins from different plant taxa. Plant Physiol 86: 134-136.

60. Grienenberger E, Kim SS, Lallemand B, Geoffroy P, Heintz D, et al. (2010) Analysis of TETRAKETIDE a-PYRONE REDUCTASE function in Arabidopsis thaliana reveals a previously unknown, but conserved, biochemical pathway in sporopollenin monomer biosynthesis. Plant Cell 22: 4067-4083 
Citation: Gómez JMG, Estébanez B, Sanz-Arranz A, Mateo-Martí E, Medina J, et al. (2016) Survival of Moss Reproductive Structures under Simulated Martian Environmental Conditions and Extreme Thermal Stress: Vibrational Spectroscopic Study and Astrobiological Implications. Astrobiol Outreach 4: 151. doi:10.4172/2332-2519.1000151

Page 10 of 11

61. Ivleva NP, Niessner R, Panne U (2005) Characterization and discrimination of pollen by Raman microscopy. Anal Bioanal Chem 381: 261-267.

62. Ihantola A, Karunen P (1977) Studies on moss spores. V. Carotenoids of Polytrichum commune. The Bryologist 80: 88-92.

63. Czeczuga B (1980) Investigations on carotenoids in embryophyta. I. Bryophyta. The Bryologist 83: 21-28.

64. Frank HA (1997) On the photophysics and photochemical properties of carotenoids and their role as light-harvesting pigments in photosynthesis. Pure Appl Chem 69: 2117-2124.

65. Vershinin A (1999) Biological functions of carotenoids--diversity and evolution. Biofactors 10: 99-104.

66. Britton G (2008) Functions of intact carotenoids. In Carotenoids Natural Functions. eds. Britton G, Liaaen-Jensen S, Pfander, H.Vol 4. Berlin, Birkhauser Verlag, pp: 189-212.

67. Merlin JC (1985) Resonance Raman spectroscopy of carotenoids and carotenoid-containing systems. Pure Appl Chem 57: 785-792.

68. Parker SF, Tavender SM, Dixon NM, Herman H, Williams KPJ, et al. (1999) Raman spectrum of beta-carotene using laser lines from green $(514.5 \mathrm{~nm})$ to near-infrared $(1064 \mathrm{~nm})$ : Implications for the characterization of conjugated polyenes. Appl Spectrosc 53: 86-91.

69. Gill D, Kilponen RG, Rimai L (1970) Resonance Raman scattering of laser radiation by vibrational modes of carotenoid pigment molecules in intact plant tissues. Nature 227: 743-744

70. Rimai L, Heyde ME, Gill D (1973) Vibrational spectra of some carotenoids and related linear polyenes. A Raman spectroscopic study. J Am Chem Soc 95: 4493-4501.

71. Schulz H, Baranska M, Baranski R (2005) Potential of NIR-FT-Raman spectroscopy in natural carotenoid analysis. Biopolymers 77: 212-221

72. Tschirner N, Schenderlein M, Brose K, Schlodder E, Andrea MM, et al. (2008) Raman excitation profiles of $B$-carotene - novel insights into the nature of the nu1-band. Phys Stat Sol (B) 245: 2225-2228.

73. Vítek P, Osterrothova K, Jehlicka J (2009) Betacarotene-a possible biomarker in the martian evaporitic environment: Raman microspectroscopic study. Planet Space Sci 57: 454-459.

74. Robert B (1999) The electronic structure, stereochemistry and resonance Raman spectroscopy of carotenoids. Kluwer Academic Publishers, pp: 189-199.

75. De Oliveira VE, Castro HV, Edwards HGM, de Oliveira LFC (2009) Carotenes and carotenoids in natural biological samples: a Raman spectroscopic analysis. J Raman Spectrosc 41: 642-650.

76. BresSson S, Marssi ME, Khelifa B (2005) Raman spectroscopy investigation of various saturated monoacid triglycerides. Chem Phys Lipids 134: 119-129.

77. De Gelder J, de Gussem K, Vandenabeele P, Moens L (2007) Reference database of Raman spectra of biological molecules. J Raman Spectrosc 38: 1133-1147.

78. Huang YY, Beal CM, Cai WW, Ruoff RS, Terentjev EM (2010) MicroRaman spectroscopy of algae: composition analysis and fluorescence background behavior. Biotechnol Bioeng 105: 889-898.

79. Karunen P (1972) Studies on moss spores I. The triglycerides of Polytrichum commune spores and their mobilization and degradation to the germination phases. Ann Univ. Turku Series AII 51: 1-70.

80. Karunen P (1975) Studies on moss spores. IV. Mass spectrometric identification of saturated and monoenoic long chain fatty acids in the triglyceride fraction of Polytrichum commune spores. Physiol Plantarum 33: 98-103.

81. Rygula A, Majzner K, Marzec KM, Kaczor A, Pilarczyk M, et al. (2013) Raman spectroscopy of proteins: a review. J Raman Spectrosc 44: 1061-1076.

82. Nakanishi K, Solomon PH (1977) Infrared Absorption Spectroscopy (2nd edn.), San Francisco, USA: Holden-Day Inc.

83. Mantsch HH, Chapman D (1996) Infrared Spectroscopy of Biomolecules, Wiley-Liss.
84. Griffiths P, De Haseth JA (2007) Fourier Transform Infrared Spectrometry (2nd edn.), John Wiley \& Sons.

85. Moh MH (1999) Quantitative analysis of palm carotene using Fourier transform infrared and near infrared spectroscopy. J Am Oil Chem Soc 76: 249-254.

86. Cao Z, Liu Y, Zhao J (2014) Efficient discrimination of some moss species by (2014) Fourier Transform infrared spectroscopy and chemometrics. J Spectrosc Article ID 191796, 9.

87. Hu T, Jin WY, Cheng CG (2011) Classification of five kinds of moss plants with the use of Fourier transform infrared spectroscopy and chemometrics. Spectroscopy 25: 271-285.

88. Zimmermann B, Kohler A (2014) Infrared spectroscopy of pollen identifies plant species and genus as well as environmental conditions. PLoS One 9: e95417.

89. Bonifacio A, Guidetti R, Altiero T, Sergo V, Rebecchi L (2012) Nature, source and function of pigments in tardigrades: in vivo raman imaging of carotenoids in Echiniscus blumi. PLoS One 7: e50162.

90. Glime JM (2007) Bryophyte Ecology. Michigan Technological University and the International Association of Bryologists.

91. Lange OL (1955) Untersuchungen über die Hitzeresistenz der Moose in Beziehung zu ihrer Verbreitung I. Die Resistenz stark ausgetrockneter Moose Flora Allg Bot Zeit 142: 381-399.

92. Rull F (2011) ExoMars Raman Laser Spectrometer for ExoMars. Proc SPIE 8152

93. Edwards HGM, Hutchinson I, Ingley R (2012) The Exomars Raman spectrometer and the identification of biogeological spectroscopic signatures using a flight-like prototype. Anal Bioanal Chem 404: 1723-1731.

94. Edwards HG, Hutchinson IB, Ingley R, Parnell J, Vítek P, et al. (2013) Raman spectroscopic analysis of geological and biogeological specimens of relevance to the ExoMars mission. Astrobiology 13: 543-549.

95. Vago J (2006) ExoMars - searching for life on the Red Planet. ESA Bull 126: 16-23.

96. Woese CR, Kandler O, Wheelis ML (1990) Towards a natural system of organisms: proposal for the domains Archaea, Bacteria, and Eucarya. Proc Natl Acad Sci U S A 87: 4576-4579.

97. Jehlička J, Edwards HG, Osterrothová K, Novotná J, Nedbalová L, et al. (2014) Potential and limits of Raman spectroscopy for carotenoid detection in microorganisms: implications for astrobiology. Philos Trans A Math Phys Eng Sci 372. (2030), 20140199.

98. Gubin SV, Maksimovich SV, Davydov SP, Gilichinskii DA, Shatilovich AV, et al. (2003) O vozmozhnosti uchastiia pozdnepleistotsenovoi bioty v formirovanii bioraznoobraziia sovremennoi kriolitozony. Zhurn Obshchei Biol 64: 160-165.

99. Wellman CH, Osterloff PL, Mohiuddin U (2003) Fragments of the earliest land plants. Nature 425: 282-285

100. Taylor TN, Taylor EL, Krings M (2009) Palaeobotany, the biology and evolution of fossil plants, $2^{\text {nd }}$ edn. Academic Press, Elsevier, Burlington.

101. Rubinstein CV, Gerrienne P, de la Puente GS, Astini RA, Steemans P (2010) Early Middle Ordovician evidence for land plants in Argentina (eastern Gondwana). New Phytol 188: 365-369.

102. Wellman $\mathrm{CH}$ (2014) The nature and evolutionary relationships of the earliest land plants. New Phytol 202: 1-3.

103. Kral TA, Goodhart TH, Harpool JD, Christopher E. Hearnsberger, et al. (2016) Sensitivity and adaptability of methanogens to perchlorates for life on Mars. Planet Space Sci 120: 87-95.

104. Rothery DA, Gilmour I, Sephton MA (2011) An Introduction to Astrobiology. 2nd ed. Edition. Cambridge University Press, UK.

105. Stark LR, McLetchie DN, Roberts SP (2009) Gender differences and new adult eukaryotic record for upper thermal tolerance in the desert moss Syntrichia caninervis. J Thermal Biol 34: 131-137.

106. McKay CP (1997) The search for life on Mars. Orig Life Evol Biosph 27: 263-289.

107. Arboleda PH, Loppnow GR (2000) Raman spectroscopy as a discovery tool in carbohydrate chemistry. Anal Chem 72: 2093-2098. 
Citation: Gómez JMG, Estébanez B, Sanz-Arranz A, Mateo-Martí E, Medina J, et al. (2016) Survival of Moss Reproductive Structures under Simulated Martian Environmental Conditions and Extreme Thermal Stress: Vibrational Spectroscopic Study and Astrobiological Implications. Astrobiol Outreach 4: 151. doi:10.4172/2332-2519.1000151

Page 11 of 11

108. Cherney DP, Conboy JC, Harris JM (2003) Optical-trapping Raman microscopy detection of single unilamellar lipid vesicles. Anal Chem 75 : 6621-6628.
109. Chan JW, Taylor DS, Lane SM, Zwerdling T, Tuscano J, et al. (2008) Nondestructive identification of individual leukemia cells by laser trapping Raman spectroscopy. Anal Chem 80: 2180-2187. 